\title{
Phylogeography of the African Common Toad, Amietophrynus regularis, Based on Mitochondrial DNA Sequences: Inferences Regarding the Cape Verde Population and Biogeographical Patterns
}

\author{
Author(s) :R. Vasconcelos, E. Froufe, J.C. Brito, S. Carranza \& D.J. Harris
}

Source: African Zoology, 45(2):291-298. 2010.

Published By: Zoological Society of Southern Africa

DOI:

URL: http://www.bioone.org/doi/full/10.3377/004.045.0207

BioOne (www.bioone.org) is a a nonprofit, online aggregation of core research in the biological, ecological, and environmental sciences. BioOne provides a sustainable online platform for over 170 journals and books published by nonprofit societies, associations, museums, institutions, and presses.

Your use of this PDF, the BioOne Web site, and all posted and associated content indicates your acceptance of BioOne's Terms of Use, available at www.bioone.org/page/terms_of_use.

Usage of BioOne content is strictly limited to personal, educational, and non-commercial use. Commercial inquiries or rights and permissions requests should be directed to the individual publisher as copyright holder. 


\title{
Phylogeography of the African common toad, Amietophrynus regularis, based on mitochondrial DNA sequences: inferences regarding the Cape Verde population and biogeographical patterns
}

\author{
R. Vasconcelos ${ }^{1,2,3^{*}}$, E. Froufe ${ }^{4}$, J.C. Brito', S. Carranza ${ }^{3}$ \& D.J. Harris ${ }^{1,2}$ \\ ${ }^{1}$ CIBIO-UP, Centro de Investigação em Biodiversidade e Recursos Genéticos, Campus Agrário de Vairão, \\ R. Padre Armando Quintas, 4485-661 Vairão, Portugal \\ ${ }^{2}$ Departamento de Biologia, Faculdade de Ciências da Universidade do Porto, R. Campo Alegre, s/n, \\ 4169-007 Porto, Portugal \\ ${ }^{3}$ Institute of Evolutionary Biology (CSIC-UPF), Passeig Maritim de la Barceloneta, 37-49, \\ E-08003 Barcelona, Spain \\ ${ }^{4}$ CIIMAR, Centro Interdisciplinar de Investigação Marinha e Ambiental, R. dos Bragas, 289, \\ 4050-123 Porto, Portugal \\ Received 1 March 2010. Accepted 2 July 2010
}

\begin{abstract}
The amphibian Amietophrynus regularis is distributed throughout equatorial Africa, with presumed introduced populations in the Cape Verde archipelago. Portions of the 12S and 16S rRNA mitochondrial regions of 30 specimens from Kenya, Uganda, Niger, Mali, Burkina-Faso, Ghana, Guinea-Bissau and Cape Verde were used to assess genetic diversity and to identify the most probable geographic origin for the introduction of this toad on the latter archipelago. Two lineages with $1.4 \%$ genetic divergence between them were identified in western and eastern Africa. All sequences from the different Cape Verde Islands were identical to each other and to the Guinea-Bissau samples, indicating, together with other historical evidences, that an anthropogenic introduction event probably occurred, possibly from Guinea-Bissau, but further work is needed to confirm this. As previously noted, several individuals from previous genetic studies seem to have been misidentified.
\end{abstract}

Key words: Amietophrynus regularis, 'Bufo', mitochondrial DNA, 12S and 16S rRNA, Cape Verde Islands.

\section{INTRODUCTION}

Amietophrynus is a large genus of 38 species of true toads native to Africa, with typically 20 chromosomes, with a complex and unresolved taxonomy. Originally, all Amietophrynus species groups were part of the genus Bufo, but were separated primarily based on molecular analyses by Frost et al. (2006) (although see criticisms in Smith \& Chiszar 2006; Pauly et al. 2009). The African common toad, Amietophrynus regularis (Reuss, 1833), also known as the square-marked toad, Egyptian and Reuss's toad, is listed as Least Concern by the IUCN in view of its wide distribution in a broad range of habitats and presumed large populations. It occurs in savannas, shrublands, grasslands, forests, rural gardens, urban areas, rivers and freshwater lakes, from near sea level up to $2500 \mathrm{~m}$ high (Tandy et al. 2006). Its range appears to be restricted by increasing aridity; in drier areas, away from permanent

\footnotetext{
*Author for correspondence.
}

E-mail: raquel.vasconcelos@mail.icav.up.pt water, it is replaced by species such as $A$. garmani and A. xeros (Tandy et al. 2006), which are morphologically similar and sympatric with $A$. regularis to some extent (Tandy et al. 2004; Rödel et al. 2006).

Amietophrynus regularis ranges from Senegal to Nilotic Egypt, Sudan and Ethiopia, southwards to western Democratic Republic of the Congo, northwestern Angola, Uganda and central-southern Kenya (Fig. 1). It is also present on the Cape Verde Islands where it is thought to have been introduced deliberately in water tanks to control mosquitoes (Schleich 1987). The oldest reference concerning the presence of toads on this archipelago, where no native amphibians occur (Schleich 1987), is from 1844 by Lopes de Lima (in Bocage 1896). It is only known to occur in Santiago, S. Nicolau and Santo Antão Islands (López-Jurado et al. 2005) (Fig. 1). The introduction of $A$. regularis to the Cape Verde Islands remains unconfirmed and the geographic origin of introduced populations and the number of introduction events undetermined. 


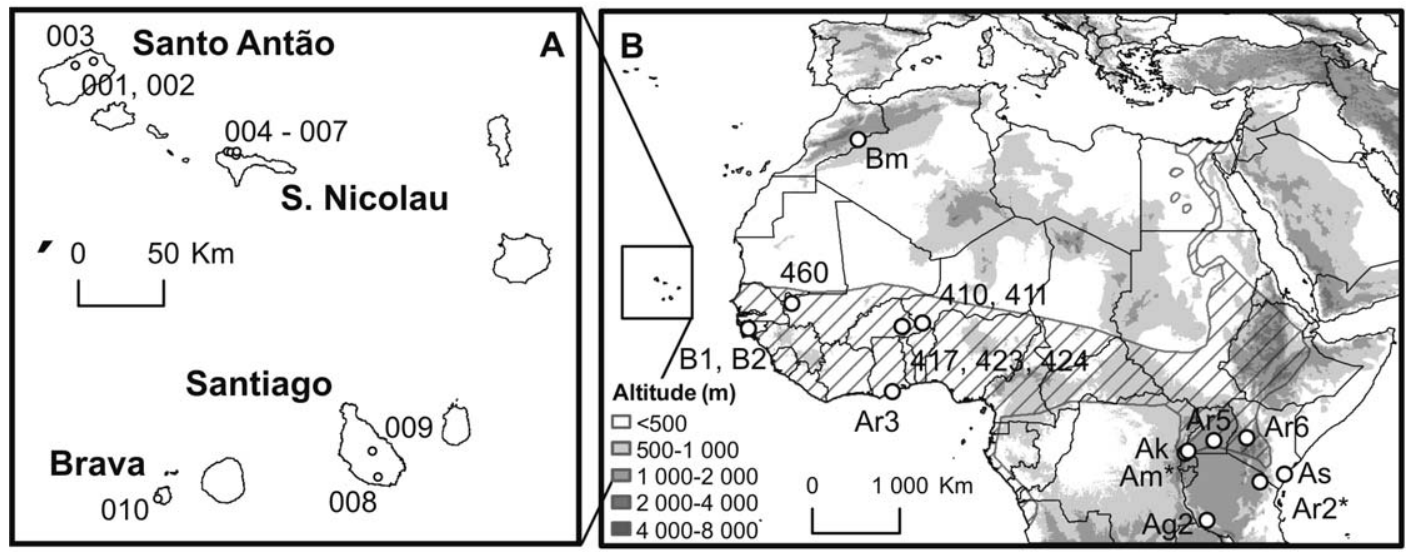

Fig. 1. Locations of the Amietophrynus and 'Bufo' sequences used in this study (A) from the Cape Verde Islands and (B) North Africa. The distribution of Amietophrynus regularis is indicated in dashed lines (adapted from Tandy et al. 2006). For codes with an asterisk $\left(^{\star}\right)$, refer to the Discussion section.

With such a wide range, it is important to determine genetic diversity within the species, in order to evaluate if geographical structure is present. By sequencing part of the $12 \mathrm{~S}$ and 16S rRNA mitochondrial region, this work will also increase the amount of data available to infer comparative phylogeographical patterns of African amphibians, as this region was already the focus of studies of 'Bufo' mauritanicus (Harris \& Perera 2009), present in the Maghreb, and A. xeros (Froufe et al. 2009), occurring in the subdesert belt. In addition, some sequences of Amietophrynus species from previous publications appear to be misidentifications, as noted by Froufe et al. (2009). Thus, a detailed reassessment of $A$. regularis with multiple individuals analysed across its range and including near relatives is needed to establish the recognition of the species group, considered paraphyletic by Frost et al. (2006) based on analyses of DNA sequences, and to ascertain if this is due to misidentification, the presence of cryptic species or because of hybridization followed by introgression. Subsequently, the objectives of this study were: 1) to determine genetic diversity across the range of $A$. regularis, 2) to ascertain the origin and number of introduction events on the Cape Verde Islands, and 3) to resolve discrepancies regarding previously published sequences.

\section{MATERIALS \& METHODS}

\section{Sampling and gathering of molecular data set}

A total of 29 sequences of Amietophrynus and one of 'Bufo' mauritanicus were used in the analysis
(Fig. 1): a) 10 from new specimens collected on the Cape Verde Islands, including one specimen from Brava where this study recorded its presence for the first time; b) eight from new specimens collected in northern African countries; and c) 12 from several African countries available on GenBank (Table 1). Digital photographs of the collected specimens were taken and a piece of toe was removed and stored in 100\% ethanol. Sampled animals were released immediately afterwards. Identification codes, localities and all GenBank accession numbers are listed in Table 1.

Total genomic DNA was extracted using standard methods, following Harris (2001). Polymerase chain reaction (PCR) primers used in amplification and sequencing of the two mitochondrial $(m t \mathrm{DNA})$ genes were $12 \mathrm{Sa}$ and $12 \mathrm{Sb}$ for the $12 \mathrm{~S}$ rRNA, 16SL and 16SH for the 16S rRNA from Kocher et al. (1989) and Palumbi et al. (1991), respectively. Thermocycling consisted of an initial 3 min at $95^{\circ} \mathrm{C}$ followed by 35 cycles of $30 \mathrm{~s}$ at $95^{\circ} \mathrm{C}$, $50^{\circ} \mathrm{C}$ and $72^{\circ} \mathrm{C}$ and then a single cycle of $7 \mathrm{~min}$ at $72^{\circ} \mathrm{C}$. Amplified mitochondrial fragments were sequenced from both strands on a 3100 Applied Biosystems DNA Sequencing Apparatus. Alignment was performed with ClustalW using Bioedit v. 5.0.9. (Hall 1999) and adjusted by hand.

\section{Phylogenetic analyses}

Sequences were imported into PAUP* $4.0 \mathrm{~b} 10$ (Swofford 2003). Four GenBank sequences of A. kisoloensis, A. gutturallis, A. steindachneri and 'Bufo' mauritanicus were used as outgroups (Table 1). 
Table 1. Details of material and sequences used in the present study. For codes with an asterisk $\left(^{\star}\right)$, refer to the Discussion section.

\begin{tabular}{|c|c|c|c|c|c|c|}
\hline Species & Code & Country & Region/Island & Latitude & Longitude & $\begin{array}{l}\text { 12s/16s } \\
\text { Genbank }\end{array}$ \\
\hline 'Bufo' mauritanicus & $\mathrm{Bm}$ & Morocco & Errachidia Province & - & - & AY680265 \\
\hline A. kisoloensis & Ak & Uganda & Rukungiri District & - & - & AY325995 \\
\hline A. steindachneri & As & Kenya & Arubuko Sokoke forest & - & - & AY325981 \\
\hline A. gutturalis & $\mathrm{Ag} 1$ & Tanzania & - & - & - & FJ882851 \\
\hline A. gutturalis & $\mathrm{Ag} 2$ & Tanzania & Mumba Village & -8.15000 & 31.85100 & DQ283436 \\
\hline A. regularis & $\operatorname{Ar}^{*}$ & - & North Africa & - & - & AY680264 \\
\hline A. regularis & $\operatorname{Ar} 2^{*}$ & Tanzania & Kilimanjaro Region & -3.99979 & 37.37750 & DQ283163 \\
\hline A. maculatus & $\mathrm{Am}^{*}$ & Uganda & Rukungiri District & -0.79114 & 29.92490 & U52762/28 \\
\hline A. regularis & Ar3 & Ghana & Eastern Region & - & - & DQ158485 \\
\hline A. regularis & Ar4 & - & Africa & - & - & AY330899/91 \\
\hline A. regularis & Ar5 & Uganda & Kampala & - & - & AF220890/43 \\
\hline A. regularis & Ar6 & Kenya & Lake Baringo & 0.60923 & 36.01560 & AF220889/43 \\
\hline A. regularis & 410 & Niger & Tapoua & 12.47480 & 2.42760 & HM769984/770002 \\
\hline A. regularis & 411 & Niger & Tapoua & 12.47480 & 2.42760 & HM769985/770003 \\
\hline A. regularis & 417 & Burkina Faso & Gourma & 12.06033 & 0.36933 & HM769986/770004 \\
\hline A. regularis & 423 & Burkina Faso & Gourma & 12.06033 & 0.36933 & HM769987/770005 \\
\hline A. regularis & 424 & Burkina Faso & Gourma & 12.06033 & 0.36933 & HM769988/770006 \\
\hline A. regularis & 460 & Mali & Kayes & 14.50400 & -11.09098 & HM769989/770007 \\
\hline A. regularis & $\mathrm{B} 1$ & Guinea-Bissau & Bissau & 11.86031 & -15.57870 & HM769990/770008 \\
\hline A. regularis & B2 & Guinea-Bissau & Bissau & 11.86031 & -15.57870 & HM769991/770009 \\
\hline A. regularis & 001 & Cape Verde & Santo Antão & 17.11363 & -25.16835 & HM769992/770010 \\
\hline A. regularis & 002 & Cape Verde & Santo Antão & 17.11363 & -25.16835 & HM769993/770011 \\
\hline A. regularis & 003 & Cape Verde & Santo Antão & 17.13884 & -25.07343 & HM769994/770012 \\
\hline A. regularis & 004 & Cape Verde & S. Nicolau & 16.66314 & -24.36332 & HM769995/770013 \\
\hline A. regularis & 005 & Cape Verde & S. Nicolau & 16.65855 & -24.34591 & HM769996/770014 \\
\hline A. regularis & 006 & Cape Verde & S. Nicolau & 16.64485 & -24.32094 & HM769997/770015 \\
\hline A. regularis & 007 & Cape Verde & S. Nicolau & 16.66047 & -24.31520 & HM769998/770016 \\
\hline A. regularis & 008 & Cape Verde & Santiago & 14.94691 & -23.57285 & HM769999/770017 \\
\hline A. regularis & 009 & Cape Verde & Santiago & 15.08491 & -23.60028 & HM770000/770018 \\
\hline A. regularis & 010 & Cape Verde & Brava & 14.83216 & -24.73434 & HM770001/770019 \\
\hline
\end{tabular}

For the phylogenetic analyses, maximum likelihood (ML) and maximum parsimony (MP) methods were used with random sequence addition (100 replicate heuristic searches). Support for nodes was estimated through bootstrap techniques (Felsenstein 1985) with 1000 replicates. Modeltest 3.06 (Posada \& Crandall 1998) was used to select the model of sequence evolution that fit the data set better using the Akaike information criterion (AIC). This model was implemented in the ML and Bayesian analyses. The Bayesian analysis was carried out using MrBayes v. 3.1 (Huelsenbeck \& Ronquist 2001), model parameters estimated as part of the analysis and four incrementally heated Markov chains with the default heating values. The analysis was run for $10^{7}$ generations, saving one tree each 1000 generations. Twenty-five per cent of the saved trees were discarded as burn-in.
It was confirmed that all parameters had ESSs above 100 after burn-in using the software Tracer v1.5 (Rambaut \& Drummond 2007). The remaining trees (7500) were combined in a 50\% majority consensus tree, in which the frequency of any particular clade represents its posterior probability (Huelsenbeck \& Ronquist 2001).

\section{Network and population analysis}

The genealogical relationships within the 23 sequences of $A$. regularis were assessed with haplotype networks constructed using statistical parsimony (Templeton et al. 1992). This analysis was implemented in the program TCS v1.21 (Clement et al. 2000) with a connection limit of 95\% and deletions treated as a fifth state. Other sequences available on GenBank only for $12 \mathrm{~S}$ or $16 \mathrm{~S}$ were not included in this analysis: AY028486 
from Ghana (Pramuk et al. 2001) and GQ183570 from Uganda, Rwenzori Mountains, Bundibuyo (Siow et al., unpubl.), respectively.

Haplotype (Hd) and nucleotide diversity $(\pi)$ values, number of haplotypes (h) and segregating sites (S) were calculated with DnaSP v.4 (Rozas et al. 2003). Estimates of average evolutionary divergence over sequence pairs within and between groups, using $p$-distances ( $p$-dist), were calculated based on the number of base differences per site from averaging over all sequence pairs within each group and estimation of net average between groups of sequences, respectively. Analyses were conducted in MEGA 4.0.2 (Tamura et al. 2007). Standard error estimates were obtained by a bootstrap procedure (1000 replicates).

\section{RESULTS}

In total, including outgroups, 30 individuals were analysed with the combined data set including $904 \mathrm{bp}$ (379 bp from $12 \mathrm{~S}$ and $525 \mathrm{bp}$ from $16 \mathrm{~S}$ rRNA), of which 106 positions were variable and 73 parsimony-informative (27 and 19 for $12 S$ and 79 and 54 for $16 \mathrm{~S}$ rRNA, respectively).

The general time reversible model (GTR), with an estimate of invariable sites $(I=0.7795)$, was the most appropriate model of evolution for this dataset. A single tree $(-\ln =2192.36412)$ was recovered from the ML analysis. Two MP trees were recovered (191 steps), the consensus of which differed from the ML tree only in some minor arrangements of taxa or individual samples. The Bayesian analysis recovered the same tree as the ML analysis. The results of the MP, ML and Bayesian analyses of the combined $12 S+16 S$ rRNA data are shown in Fig. 2 and indicate that two lineages, western and eastern, exist within A. regularis. The genetic distance between these lineages is $1.4 \pm 0.4 \%$ (Table 2). In addition, two sequences identified as $A$. regularis in previous studies, Ar1* and Ar2* (with GenBank codes AY680264 and DQ283163, respectively) cluster with A. kisoloensis and A. gutturalis, respectively, whereas one sequence assigned to $A$. maculatus (Am*, U52728/62) groups within the eastern lineage of $A$. regularis (Fig. 2).

According to the network analyses, the western and eastern $A$. regularis lineages are 13 mutational steps apart (Fig. 3). In the western lineage, all sequences from the four Cape Verde Islands are identical to each other and to the Guinea-Bissau sequences. By contrast, sequences from individuals from Mali, Ghana, Burkina Faso and Niger are between one and three mutational steps apart from those sequences of individuals from the Cape Verde Islands (Fig. 3). After preliminary analysis, the sample Ar4 (AY330899/91) of an unknown locality (Table 1) was assumed to belong to the eastern lineage due to its affinities with this clade. As a result, in the eastern lineage, four closely connected haplotypes were recovered (Fig. 3).

\section{DISCUSSION}

The phylogenetic analyses showed that two distinct mitochondrial lineages of $A$. regularis appear to exist, one in the western and another in the eastern part of Africa with a genetic divergence of $1.4 \%$ ( $1.5 \%$ based only on $16 \mathrm{~S}$ rRNA). Divergence levels between these western and eastern lineages could be explained by isolation through geographic distance alone or together with geographical barriers such as high mountains (Fig. 1). Few anuran phylogeographic studies from northern Africa exist and the ones using the same molecular markers, the Maghrebian B. mauritanicus and the sub-Saharan $A$. xeros, recovered very different patterns. The former presents minimal genetic variation within its range (Harris \& Perera 2009) and the latter exhibits maximal divergence between samples from the same country (Froufe et al. 2009). However, an assessment of variation in the rodent Mastomys erythroleucus with the same geographical range as $A$. regularis recovered a similar pattern to the one presented here, although with two additional central African lineages (Brouat et al. 2009). Thus, further sampling of A. regularis in Central Africa would be needed to define the ranges of the eastern and western lineages and to assess if additional lineages could be uncovered. Furthermore, it would be useful to sample isolated populations in the Sahara, such as in the Hoggar mountains of southern Algeria and in the oasis of southwestern Libya (Schleich et al. 1996), to confirm its presence and determine if more variation exists.

Considering the Cape Verde Islands, it seems that this species is indeed introduced there and that a single introduction event occurred, as all individuals from the four islands where the species occurs have the same mitochondrial haplotype. Nevertheless, a scenario of multiple colonizations from the same source population is also possible and further SNPs or microsatellites analyses would be needed to distinguish with certainty between the two scenarios. The network analysis indicates Guinea-Bissau as the most likely source of the introduction of $A$. regularis on the Cape 


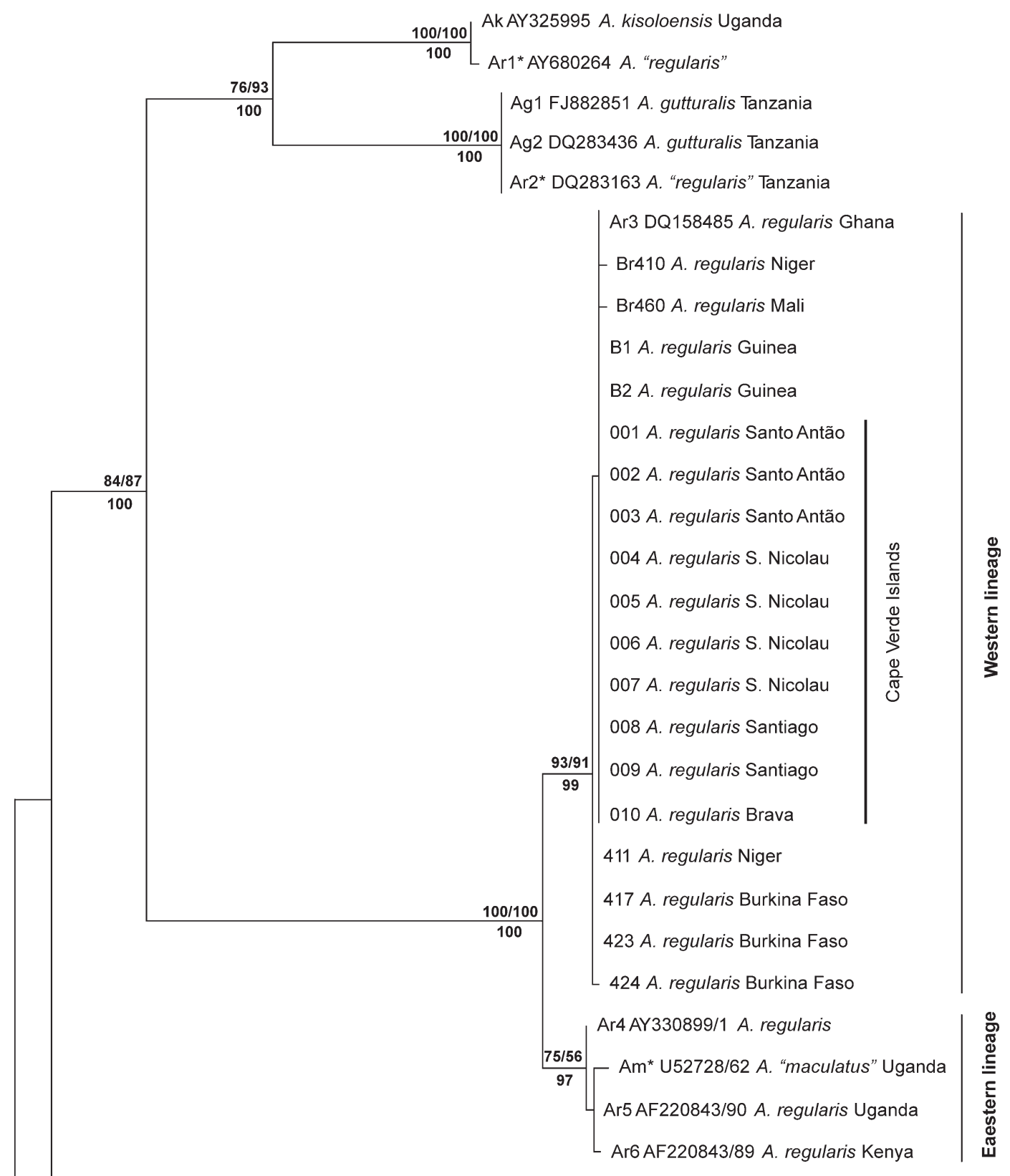

As AY325981 A. steindachneri Kenya

Bm AY680265 "Bufo" mauritanicus Morocco

0.005 substitutions/site

Fig. 2. Maximum likelihood (ML) tree inferred using the GTR+I model of sequence evolution showing relationships of Amietophrynus regularis from different origins. The tree is rooted using 'Bufo' mauritanicus. Bootstrap support values above $50 \%$ for the MP and ML analysis are shown above nodes, respectively, and posterior probability values for the Bayesian analysis below nodes (see Materials \& Methods). Sequences downloaded from GenBank are shown in the figure with their respective GenBank accession numbers for the 16S and 12S rRNA genes separated by a slash if the accession numbers differ. For locality data and GenBank accession numbers of the new (ranging from HM769984 to HM770019) and previously published sequences see Table 1. 
Table 2. Mitochondrial $12 S$ and $16 S$ diversity of the western and eastern lineages of Amietophrynus regularis. $n$, sample size; $\pi$, nucleotide diversity; $\mathrm{Hd}$, haplotype diversity; $\mathrm{h}$, number of haplotypes; $\mathrm{S}$, segregating sites; evolutionary divergence within and between groups ( $p$-dist \pm standard error).

\begin{tabular}{lrllllll}
\hline Lineage & $n$ & $\pi$ & $\mathrm{h}$ & $\mathrm{Hd}$ & $\mathrm{S}$ & $p$-dist & $p$-dist \\
\hline Western & 19 & 0.00095 & 7 & 0.574 & 4 & $0.2 \pm 0.1 \%$ & $1.4 \pm 0.4 \%$ \\
Eastern & 4 & 0.00194 & 4 & 1.000 & 3 & $0.1 \pm 0.1 \%$ & \\
\hline
\end{tabular}

Verde Islands, given that samples from both regions share the same haplotype. This seems feasible as the Portuguese made regular trips during the 16th and 17th centuries from Guinea-Bissau to the previously uninhabited archipelago for colo- nizing it with a slave workforce and as a strategic stopping point of the slavery trade route between Guinea-Bissau and the American continent (Silva 1995). However, as samples from other West African areas are lacking and other sequences from

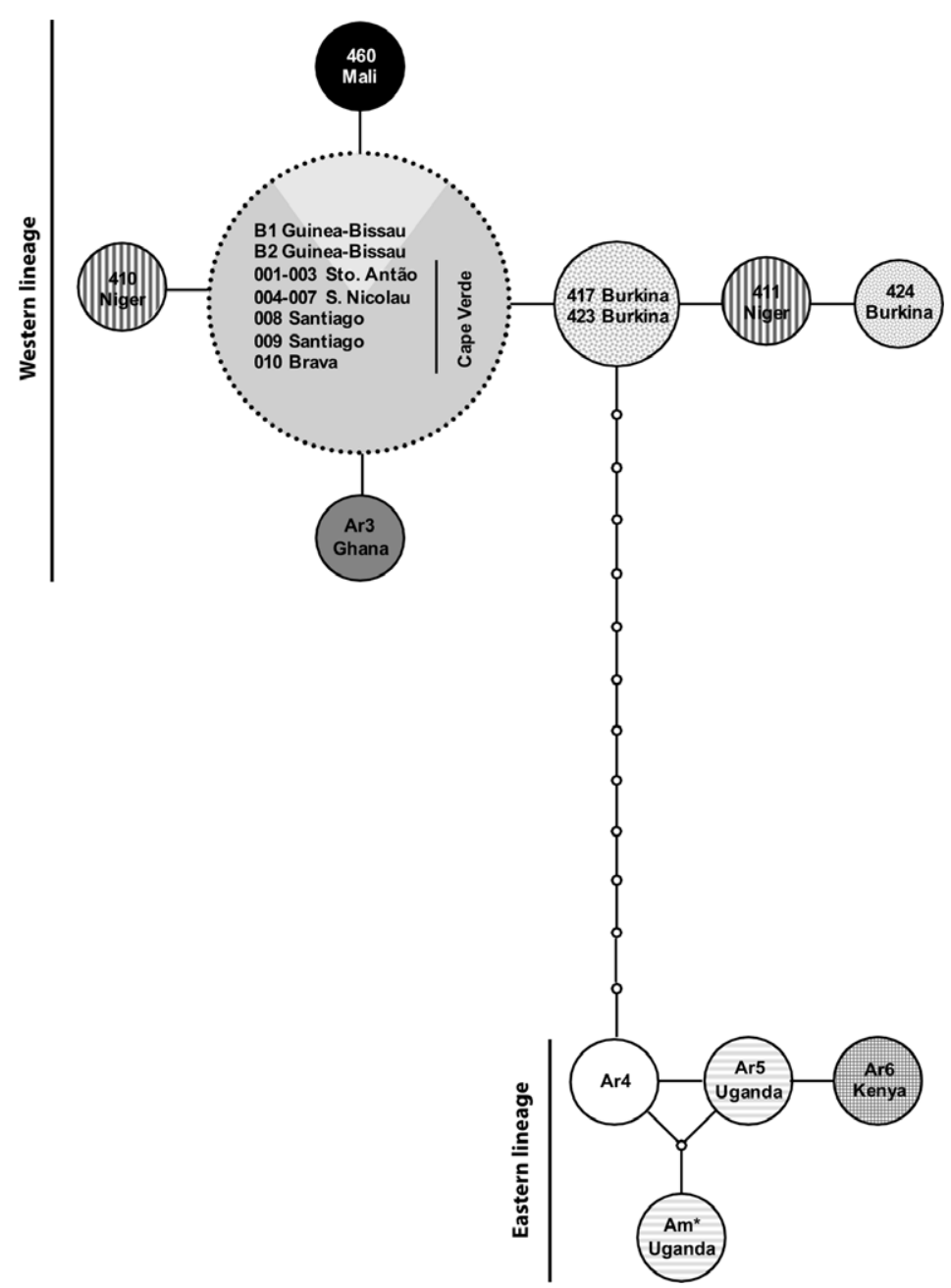

Fig. 3. Parsimony network corresponding to the $12 \mathrm{~S}$ and $16 \mathrm{~S}$ rRNA sequence variation in Amietophrynus regularis. Lines represent a mutational step, circles haplotypes and dots missing haplotypes. The size of the circle is proportional to the number of individuals. The dotted circle represents the probable ancestral haplotype. Samples from the same country are indicated using the same pattern or grey scale. For sample and location codes see Table 1 . For codes with an asterisk $\left({ }^{*}\right)$, refer to the Discussion section. 
different origins are only one to three mutational steps away from the Cape Verde sequences, an alternative origin for $A$. regularis found on the Cape Verde Islands cannot be ruled out.

Since no other native amphibian exists on the islands, the presence of $A$. regularis probably does not raise any direct conservation issues, contrary to other accidentally introduced herpetofauna occurring on the Cape Verdes, such as Hemidactylus angulatus, H. mabouia (Arnold et al. 2008) and Agama agama (Vasconcelos et al. 2009). However, the impact that $A$. regularis might have on native invertebrates or indirectly on the vertebrate community dynamics is unknown. It is known to be abundant in Santiago, S. Nicolau and Santo Antão (Hazevoet 1995) and it was considered invasive by López-Jurado et al. (2005) on the archipelago. This study reports it for the first time on Brava. Further studies are clearly warranted to assess its impact on this insular ecosystem.

Finally, as previously noted by Froufe et al. (2009), the Ar1* (AY680264; Pauly et al. 2004) and $\mathrm{Am}^{*}$ sequences (U52728/62; Graybeal 1997) are probably morphological misidentifications rather than introgression, sequencing errors, contaminations or amplification of nuclear copies of the $m t$ DNA. An additional sequence of $A$. 'regularis', Ar2* (DQ283163; Frost et al. 2006), appears identical to A. gutturalis specimens sequenced by Frost et al. (2006) and Van Bocxlaer et al. (2009). This study again emphasizes the importance of using multiple individuals of the same species in phylogenetic analyses and of including sequences from GenBank with caution. Additionally, as some Amietophrynus are morphologically similar, with some individuals presenting ambiguous morphological characters used in identification keys (J. Brito, pers. obs.), future work with nuclear genes should be done to confirm the estimates of relationships based on $m t \mathrm{DNA}$ sequence data. Also additional morphological studies should be implemented in order to try to find clearly diagnostic characters.

\section{ACKNOWLEDGEMENTS}

Thanks to the two anonymous reviewers who made constructive comments on an earlier version of the manuscript. This study was funded by a project from Fundação para a Ciência e Tecnologia (FCT): PTDC/BIA-BDE/74288/2006 (to D.J.H.). R.V. has a doctoral FCT grant (SFRH/BD/25012/2005), E.F., D.J.H. and J.C.B. have contracts (Programa Ciência 2007 and 2008 - Fundo Social Europeu) from FCT. Fieldwork was partially supported by a grant from National Geographic Society (7629-04). S.C. was supported by grants CGL2009-11663 and 2009SGR-1462. We wish to thank to R. Rebelo and G. Rosa for the Guinea-Bissau samples; S. Rocha, M. Fonseca and A. Perera from CIBIO for help during fieldwork in Cape Verde; J. Roca for lab assistance; to Eng. J. César, Dr Domingos, Eng. Orlando, Eng. Lenine, and staff from Ministério da Agricultura e Ambiente (MAA), Cape Verde and to I. Gomes and all staff from Instituto Nacional de Investigação e Desenvolvimento Agrário (INIDA), Cape Verde for logistical support. Samples were obtained according to license no. 07/2008 by Direcção Geral do Ambiente, MAA, Cape Verdean Government.

\section{REFERENCES}

ARNOLD, E.N., VASCONCELOS, R., HARRIS, D.J., MATEO, J.A. \& CARRANZA, S. 2008 Systematics, biogeography and evolution of the endemic Hemidactylus geckos (Reptilia, Squamata, Gekkonidae) of the Cape Verde Islands: based on morphology and mitochondrial and nuclear DNA sequences. Zoologica Scripta 37: 619-636.

BOCAGE, J.V. 1896. Reptis de Algumas possessões portuguezas d'Africa que existem no Museu de Lisboa. Jornal de Sciencias Mathematicas, Physicas e Naturaes, Academia Real das Sciencias de Lisboa 14: 1-9.

BROUAT, C., TATARD, C., BÂ, K., COSSON, J.F., DOBIGNY, G., FICHET-CALVET, E., GRANJON, L., LECOMPTE, E., LOISEAU, A., MOULINE, K. \& DUPLANTIER, J.M. 2009. Phylogeography of the Guinea multimammate mouse (Mastomys erythroleucus): a case study for Sahelian species in West Africa. Journal of Biogeography 36: 2237-2250.

CLEMENT, M., POSADA, D. \& CRANDALL, K.A. 2000. TCS: a computer program to estimate gene genealogies. Molecular Ecology 9: 1657-1660.

FELSENSTEIN, J. 1985. Confidence limits on phylogenies: an approach using bootstrap. Evolution 39: 783-791.

FROST, D.R., GRANT, T., FAIVOVICH, J., BAIN, R.H., HAAS, A., HADDAD, C.F.B., DE SÁ, R.O., CHANNING, A., WILKINSON, M., DONNELLAN, S.C., RAXWORTHY, C.J., CAMPBELL, J.A., BLOTTO, B.L., MOLER, P., DREWES, R.C., NUSSBAUM, R.A., LYNCH, J.D., GREEN, D.M. \& WHEELER, W.C. 2006. The Amphibian tree of life. Bulletin of the American Museum of Natural History 297: 1-370.

FROUFE, E., BRITO, J.C. \& HARRIS, D.J. 2009. Phylogeography of North African Amietophrynus xeros estimated from mitochondrial DNA sequences. African Zoology 44: 208-215.

GRAYBEAL, A. 1997. Phylogenetic relationships of bufonid frogs and tests of alternate macroevolutionary hypotheses characterizing their radiation. Zoological Journal of the Linnean Society 119: 297-338.

HALL, T.A. 1999. Bioedit: a user friendly biological sequence alignment editor and analysis program for 
Windows 95/98/NT. Nucleic Acids Symposium Series 41: 95-98.

HARRIS, D.J. 2001. Reevaluation of $16 S$ ribosomal RNA variation in Bufo (Anura: Amphibia). Molecular Phylogenetics and Evolution 19: 326-329.

HARRIS, D.J. \& PERERA, A. 2009. Phylogeography and genetic relationships of North African Bufo mauritanicus Schlegel, 1841 estimated from mitochondrial DNA sequences. Biologia 64: 1-5.

HAZEVOET, C.J. 1995. The Birds of the Cape Verde Islands. B.O.U. Check-list no. 13. Brithish Orniltologists' Union, Tring, U.K.

HUELSENBECK, J.P. \& RONQUIST, F. 2001. Mr. Bayes: Bayesian inference of the phylogeny. Bioinformatics 17: 754-755.

KOCHER, T.D., THOMAS, W.K., MEYER, A., EDWARDS, S.V., PÄÄBO, S., VILLABLANCA, F.X. \& WILSON, A.C. 1989. Dynamics of mitochondrial DNA evolution in animals: amplification and sequencing with conserved primers. Proceedings of the National Academy of Science USA 86: 6196-6200.

LÓPEZ-JURADO, L.F., MATEO, J.A. \& FAZERES, A.I. 2005. Chordata. In: Lista Preliminar de Espécies Silvestres de Cabo Verde. Hongos, Plantas y Animales Terrestres, (eds) M. Arechavaleta, N. Zurita, M.C. Marrero \& J.L. Martín, 1st edn, p. 101. Gobierno de Canárias, Consejería de Médio Ambiente, Islas Canárias.

PALUMBI, S., MARTIN, A., ROMANO, S., McMILLAN, W., STICK, L. \& GRABOWSKI, G. 1991. The Simple Fools Guide to PCR. Version 2. Publisher, Honolulu, Hawaii.

PAULY, G.B., HILLIS, D.M. \& CANNATELLA, D.C. 2004. The history of a Nearctic colonization: molecular phylogenetics and biogeography of the Nearctic toads (Bufo). Evolution 58: 2517-2535.

PAULY, G.B., HILLIS, D.M. \& CANNATELLA, D.C. 2009. Taxonomic freedom and the role of official lists of species names. Herpetologica 65:115-128.

POSADA, D. \& CRANDALL, K.A. 1998. Modeltest: testing the model of DNA substitution. Bioinformatics 14: $817-818$

PRAMUK, J.B., HASS, C.A. \& HEDGES, S.B. 2001. Molecular phylogeny and biogeography of West Indian toads (Anura: Bufonidae). Molecular Phylogenetics and Evolution 20: 294-301.

PRAMUK, J.B. 2006. Phylogeny of South American Bufo (Anura: Bufonidae) inferred from combined evidence. Zoological Journal of the Linnean Society 146: 407-452.

RÖDEL, M.O., LARGEN, M., HOWELL, K., TANDY, M., SALVADOR, A., LÖTTERS, S., GENIEZ, P. 2006. Amietophrynus xeros. In: IUCN 2010. IUCN Red List of Threatened Species, Version 2010.1. Online at: http://www.iucnredlist.org (downloaded on 13 April 2010).
ROZAS, J., SÁNCHEZ-DELBARRIO, J.C., MESSEGUER, X. \& ROZAS, R. 2003. DnaSP, DNA polymorphism analyses by the coalescent and other methods. Bioinformatics 19: 2496-2497.

RAMBAUT, A. \& DRUMMOND A.J. 2007. Tracer v1.4. Online at: http://beast.bio.ed.ac.uk/Tracer

SCHLEICH, H. H. 1987. Herpetofauna Caboverdiana. Spixiana 12: 1-75.

SCHLEICH, H.H., KÄSTLE, W. \& KABISCH, K. 1996. Amphibians and Reptiles of North Africa. Koeltz Scientific Books, Koenigstein, Germany.

SILVA, A. 1995. Cabo Verde e a Geopolítica do Atlântico. In: História Geral de Cabo Verde: Volume II, (ed.) M.E. Santos, 1st edn, pp. 1-16. Instituto de Investigação Científica Tropical, Lisboa \& Instituto Nacional da Cultura de Cabo Verde, Praia.

SMITH, H.M. \& CHISZAR, D. 2006. Dilemma of name recognition: Why and when to use new combinations of scientific names. Herpetological Conservation and Biology 1: 6-8.

SWOFFORD, D.L. 2003. PAUP* ver 4.0.b10. Phylogenetic Analysis Using Parsimony ( ${ }^{*}$ and Other Methods). Sinauer Associates, Sunderland, Massachusetts.

TAMURA, K., DUDLEY, J., NEI, M. \& KUMAR, S. 2007. MEGA4: Molecular Evolutionary Genetics Analysis (MEGA) software version 4.0. Molecular Biology and Evolution 24: 1596-1599.

TANDY, M., POYNTON, J., LARGEN, M., HOWELL, K., CHANNING, A., MINTER, L. \& LÖTTERS, S. 2004. Amietophrynus garmani. In: IUCN 2010. IUCN Red List of Threatened Species, Version 2010.1. Online at: http://www.iucnredlist.org (downloaded on 13 April 2010).

TANDY, M., RÖDEL, M.O., LARGEN, M., POYNTON, J.C., LÖTTERS, S., EL DIN, S.B. \& GERSON, H. 2006. Amietophrynus regularis. In: IUCN 2010. IUCN Red List of Threatened Species, Version 2010.1. Online at: http://www.iucnredlist.org (downloaded on 13 April 2010).

TEMPLETON, A.R., CRANDALL, K.A. \& SING, C.F. 1992. A cladistic analysis of phenotypic associations with haplotypes inferred from restriction endonuclease mapping and DNA sequence data. III. Cladogram estimation. Genetics 132: 619-633.

VAN BOCXLAER, I., BIJU, S.D., LOADER, S.P. \& BOSSUYT, F. 2009. Toad radiation reveals into-India dispersal as a source of endemism in the Western Ghats - Sri Lanka biodiversity hotspot. BMC Evolutionary Biology 9: 131.

VASCONCELOS, R., ROCHA, S., BRITO, J.C., HARRIS, D.J. \& CARRANZA, S. 2009. First report of introduced African rainbow Lizard Agama agama (Linnaeus, 1758) in the Cape Verde Islands. Herpetozoa 21: 183-186.

Responsible Editor: P.leF.N. Mouton 